Article

\title{
Antiobesity Effects of Extract from Spergularia marina Griseb in Adipocytes and High-Fat Diet-Induced Obese Rats
}

\author{
Yong-Hyun Park ${ }^{1,+}$, Jae-Joon Lee ${ }^{1,+}$, Hee-Kyoung Son ${ }^{1}$, Bok-Hee Kim ${ }^{1}$, Jaemin Byun ${ }^{2}$ and \\ Jung-Heun $\mathrm{Ha}^{3, * \mathbb{D}}$ \\ 1 Department of Food and Nutrition, Chosun University, Gwangju 61452, Korea; \\ yonghyunpark@hanmail.net (Y.-H.P.); leejj80@chosun.ac.kr (J.-J.L.); kyoung1033@dankook.ac.kr (H.-K.S.); \\ kimbh@chosun.ac.kr (B.-H.K.) \\ 2 Center for Discovery and Innovation, Hackensack Meridian Health, Nutley, NJ 07110, USA; \\ jaemin.byun@hmh-cdi.org \\ 3 Department of Food Science and Nutrition, Dankook University, Cheonan 31116, Korea \\ * Correspondence: ha@dankook.ac.kr; Tel.: +82-41-550-3479 \\ + These authors contributed equally to this work.
}

Received: 25 December 2019; Accepted: 23 January 2020; Published: 27 January 2020

\begin{abstract}
Obesity has recently risen and become a serious health concern in Korea according to the westernized diet and altered lifestyle. Hence, there is a growing interest in the supplementation of phytochemicals to find a safe and effective functional ingredient to treat obesity. Spergularia marina Griseb (SM) has traditionally been used as a natural herb against chronic diseases in Korea. In this study, we investigated the antiobesity effects of SM in vitro and in vivo. SM ethanol extract (SME) inhibited proliferation and differentiation in murine adipocytes and primary porcine pre-adipocytes in a dose-dependent manner. In the in vivo study, supplementation of SM powder (SMP) remarkably attenuated fat accumulation in HFD-induced obese rats. In addition, SMP supplementation improved lipid profiles in the serum and tissues of high-fat induced obese rats. Collectively, these data indicated that SME exhibited antiobesity effects by modulating adipogenesis and lipolysis. Furthermore, SMP could be developed as an obesity-induced metabolic syndrome treatment.
\end{abstract}

Keywords: antiobesity; Spergularia marina Griseb; adipocyte; differentiation; high-fat diet; obese rat

\section{Introduction}

Obesity is characterized as an excessive accumulation of adipose tissue in the body [1]. Recently, obesity has increased and has become a serious public health and social concern in Korea [2] and in the world [3], based on the excessive caloric intake and altered lifestyle [4]. Due to rapid economic growth and dietary changes in Korea, the number of obese patients has increased [5]. Obesity is related to significant health problems due to excessive fat and related pathophysiology. Notably, obesity results in increased risks for type 2 diabetes mellitus (T2DM), cardiovascular diseases (CVD), stroke, osteoarthritis, and cancers [6,7]. At cellular level, lipid accumulation develops according to proliferation and/or de novo differentiation of adipocytes [8], with the accumulation of fat due to hyperplasia or hypertrophy of adipocytes [9]. The fat depot in cells is regulated by either lipogenesis or lipolysis [10]. To treat obesity, pharmacological approaches have been developed for the management of lipogenesis and lipolysis. However, these treatments inherently cause side effects, such as diabetes, CVD, cerebrovascular disease, and sleep apnea [11]. Therefore, there is a growing interest to find safer and efficacious functional ingredients to control obesity using plant-based natural sources. Various natural ingredients, crude extracts or single derived compounds, have been shown to inhibit adipocyte 
proliferation and/or differentiation, including Garcinia cambogia, chili pepper, Panax ginseng, brown algae, garlic, and flaxseed [12].

Spergularia marina Griseb (SM) is a kind of halophyte (salt-tolerant plant) that grows in mudflats at shores. In Korea, SM has been proven as an edible herb, identified to have mitigating effects against chronic disease [13]. Furthermore, the composition of SM has recently been elucidated by individual isolation [14], evaluation of physiological activity [13], and physiochemical characterization by blanching [15], demonstrating improved insulin sensitivity [16]. However, there are limited data supporting the activity of SM against excessive fat accumulation or its underlying mechanism. In this study, we investigated the antiobesity effects of SM and evaluated the potential of SM as a functional material for antiobesity. In vitro, the ethanol extracts of SM (SME) were evaluated for proliferation and differentiation in 3T3-L1 pre-adipocytes and primary porcine pre-adipocytes in a dose-dependent manner. In vivo, the effect of the SM powder (SMP) supplement was evaluated to elucidate its potential role in obesity, through body weight regulation. Furthermore, we evaluated the effect of SMP on lipid metabolism in the blood, liver, and adipose tissues in high-fat diet-induced obese rats.

\section{Materials and Methods}

\subsection{Chemicals and Reagents}

The 3T3-L1 preadipocytes were purchased from the American Type Culture Collection (ATCC). Dulbecco's modified Eagle's medium (DMEM), DMEM/F-12 medium, fetal bovine serum (FBS), penicillin-streptomycin (PS), and phosphate-buffered saline (PBS) were purchased from Gibco Laboratory (Grand Island, NY, USA). The 3-isobutyl-1-methylxanthine (IBMX), dexamethasone (Dex), insulin, 3-(4,5-Dimethylthiazol-2-yl)-2,5-Diphenyltetrazolium bromide (MTT), dimethyl sulfoxide (DMSO), Oil Red O, and hematoxylin and eosin (H\&E) reagents were purchased from Sigma-Aldrich Co. (St. Louis, MO, USA). For in vivo analysis, triglyceride (TG), total cholesterol (TC), and high-density lipoprotein cholesterol (HDL-C) kits were purchased from Asan Pharmaceutical (Seoul, Korea).

\subsection{Preparation of Materials}

SM was obtained from Mu-An, Jeollabuk-Do, South Korea. SM was washed three times with water and dried using a salad spinner (Caous, WINDAX, Seoul, Korea). Next, SM was frozen in an ultra-freezer (MDF-U 52V, Sanyo, Osaka, Japan) at $-70{ }^{\circ} \mathrm{C}$ and dried for $72 \mathrm{~h}$ in the freeze dryer (ED 8512, Il-shin, Yangju, Korea). Frozen dried SM was powdered using a grinder (HR2904, Philips Co., the Netherlands) and stored at $-70{ }^{\circ} \mathrm{C}$ (SM powder, SMP). One hundred grams of frozen dried SMP was added to $1500 \mathrm{~mL} 80 \%$ ethanol and extracted for $3 \mathrm{~h}$, three times using a heating mantle. The extract was filtered using a Whatman No. 2 paper and evaporated under reduced pressure in a vacuum rotary evaporator (EYELA VACUUM NVC-1100, Tokyo, Japan). Next, the extract was freeze-dried and stored at $-70{ }^{\circ} \mathrm{C}$ (SM ethanol extract, SME).

\subsection{Cell Culture}

The 3T3-L1 pre-adipocyte cells were cultured as previously described [17]. Cells were maintained as pre-adipocytes in DMEM supplemented with 10\% FBS and 1\% PS. To differentiate 3T3-L1 pre-adipocytes to adipocytes, we added $10 \mu \mathrm{g} / \mathrm{mL}$ insulin, $1.0 \mu \mathrm{M}$ Dex, and $0.5 \mathrm{nM}$ IBMX on the first day, and only insulin was added from the second day for differentiation. Cells were incubated with $37^{\circ} \mathrm{C}$ in a humidified atmosphere consisting of $95 \%$ air and $5 \% \mathrm{CO}_{2}$. Porcine pre-adipocytes were isolated from the back (or retroperitoneal) fat tissues of 1-day males. Fat tissues were dissected and finely minced after removing all visible connective tissues. The minced tissues were incubated with collagenase (Roche, Basel, Switzerland) solution for $40 \mathrm{~min}$ in shaking water bath. The mixture solution was filtered through a $25 \mu$ m nylon screen (Falcon, Corning, NY, USA) and centrifugated at $1500 \times g$ for $10 \mathrm{~min}$. Cell pellet was resuspended in Kreb's Ringer bicarbonate buffer and centrifuged at $1796 \times g$ for $10 \mathrm{~min}$. Next, porcine pre-adipocytes were cultured as previously reported [18]. Briefly, the number of 
harvested pre-adipocytes was measured using the hematocytometer and cells were plated in a dish with DMEM medium containing 10\% FBS. Then, the cells were continuously incubated for 2 days with DMEM/F-12 medium containing 10\% FBS, $600 \mathrm{ng} / \mathrm{mL}$ insulin, $0.1 \mu \mathrm{g} / \mathrm{mL}$ transferrin, $500 \mathrm{ng} / \mathrm{mL}$ hydrocortisone, and $0.05 \mu \mathrm{M}$ rosiglitazone until the day of differentiation measurement. After the differentiation of pre-adipocytes, cells were subjected to glycerol-3-phosphate dehydrogenase (GPDH) assays, triglyceride content, and lipoprotein lipase (LPL) activity analysis on day 8.

\subsection{Cell Viability}

Cells were treated with DMSO (control) or dose-dependent SME (50-200 $\mu \mathrm{g} / \mathrm{mL}$ ) for $48 \mathrm{~h}$. Cell viability was monitored using the MTT assay. The absorbance was measured at $540 \mathrm{~nm}$ using an ELISA microplate reader (Model 680, BioRad Laboratories Inc., Hercules, CA, USA).

\subsection{Glycerol-3-phosphate Dehydrogenase (GPDH) Measurement}

The differentiation of 3T3-L1 pre-adipocytes and the porcine pre-adipocytes was investigated by measuring of GPDH activity as previously described [19]. Briefly, the cells were washed with PBS and collected in a homogenizing buffer. After centrifugation, the supernatant was mixed with the assay buffer and substrates. The mixture solution was measured to analyze the activity of GPDH at $340 \mathrm{~nm}$ using an ELISA microplate reader.

\subsection{Measurement of Lipoprotein Lipase (LPL) Activity}

The determination of LPL activity was performed as previously reported [20]. One unit of LPL activity was defined as the release of $1 \mu \mathrm{mol}$ of free fatty acid in $1 \mathrm{~h}$. Glycerol stabilized $3 \mathrm{H}$-triolein emulsion was used as the substrate for the measurement.

\subsection{Quantification of Triglyceride (TG) Contents}

To analyze the content of cellular TG, cells were washed with PBS and sonicated. The supernatant was collected by centrifugation at $1792 \times g$ at $4{ }^{\circ} \mathrm{C}$ after incubation on ice for $30 \mathrm{~min}$. The supernatant was mixed with the free glycerol assay reagent in a 96-well plate. After incubation for $5 \mathrm{~min}$ at $37^{\circ} \mathrm{C}$, the absorbance of the solution was measured at $540 \mathrm{~nm}$ using a microplate reader.

\subsection{Animal Experiments and Diets}

All animal studies were approved by the Chosun University Institutional Animal Care and Use Committee (C IACUC 2014-A0029). Sprague-Dawley male rats ( $n=32,5$ weeks old) were purchased from Orient Bio, Inc. (Seongam-Si, Korea). The animals were housed at a temperature of $18 \pm 2{ }^{\circ} \mathrm{C}$, a humidity of 55\% $\pm 5 \%$, and with a $12 \mathrm{~h}$ light-dark cycle (08:00-20:00) at the Center for Animal Experiment. The animals had access to water and food ad libitum. After 1 week of an adaptation period, the rats were randomized into four groups ( $n=8$ per group). The rats in each group were fed a normal diet (ND, 31\% of calories as fat), a high-fat diet (HFD, $46 \%-48 \%$ of calories as fat), HFD with SMP low supplement (HFD-SL, HFD + 3\% of SMP), or a HFD and with SMP high supplement (HFD-SH, HFD $+5 \%$ of SMP) for 4 weeks. The composition of the experimental diet is shown in Table 1. Body weight (BW) and food intake were measured once a week. The food efficiency ratio (FER) was calculated as FER = (total BW gain/total food intake). At the end of the study, blood samples were collected from the inferior vena cava and centrifuged at $1150 \times g$ for $20 \mathrm{~min}$, and a supernatant (serum) was obtained. The liver and adipose tissues were harvested and weighed after washing with $0.9 \%$ saline. Tissue and serum samples were preserved at $-80{ }^{\circ} \mathrm{C}$ until analysis. 
Table 1. Composition of experimental diet.

\begin{tabular}{|c|c|c|c|c|}
\hline Diet Composition $\left(\mathrm{g}^{1}\right)$ & $\mathrm{ND}^{2}$ & HFD $^{3}$ & HFD-SL & HFD-SH \\
\hline Casein & 200 & 200 & 200 & 200 \\
\hline L-Cystine & 3 & 3 & 3 & 3 \\
\hline Corn starch & 399.986 & 299.986 & 269.986 & 249.986 \\
\hline Dextrose & 100 & 100 & 100 & 100 \\
\hline Sucrose & 50 & 50 & 50 & 50 \\
\hline Cellulose & 50 & 50 & 50 & 50 \\
\hline Lard & 100 & 200 & 200 & 200 \\
\hline Soybean oil & 50 & 50 & 50 & 50 \\
\hline Mineral mix 4 & 35 & 35 & 35 & 35 \\
\hline Vitamin mix 5 & 10 & 10 & 10 & 10 \\
\hline Choline chloride & 2 & 2 & 2 & 2 \\
\hline tert-Butylhydroquinone & 0.014 & 0.056 & 0.056 & 0.056 \\
\hline Spergularia marina Griseb & 0.0 & 0.0 & 30 & 50 \\
\hline Total (g) & 1000 & 1000.042 & 1000.042 & 1000.042 \\
\hline Total energy (kcal) & 4401.94 & 4901.944 & 4781.944 & 4701.944 \\
\hline Fat (kcal \%) & 30.67 & 45.90 & 47.05 & 47.85 \\
\hline
\end{tabular}

\subsection{Biochemical Analysis of Serum Samples}

The activities of aspartate aminotransferase (AST), alanine aminotransferase (ALT), alkaline phosphatase (ALP), lactate dehydrogenase (LDH), TG, total cholesterol (TC), HDL-C, and glucose (Glu) levels in serum were measured using the Chemistry Analyzer (Fujifilm Dri-C hem 3500i, Fujifilm, Tokyo, Japan). The value of low-density lipoprotein cholesterol (LDL-C) was calculated using the Friedwald formula [21] (LDL-C $=\mathrm{TC}-(\mathrm{HDL}-\mathrm{C}-\mathrm{TG} / 5)$ ). Atherogenic index (AI) was calculated using the formula ((TC - HDL-C)/HDL-C) and cardiac risk factor (CRF) was obtained using (TC/HDL-C) [22].

\subsection{Lipid Contents of Liver and Adipose Tissues}

Lipids were extracted from $\sim 0.1 \mathrm{~g}$ of the liver and adipose tissues as described previously [23]. Briefly, the tissues were homogenized in a chloroform/methanol (2:1 v/v) mixture and centrifuged at $1150 \times g$ for $20 \mathrm{~min}$. TG and TC were measured from the lower layer (lipid abundant) using previously reported methods [24,25].

\subsection{Histological Analysis}

Liver tissues were fixed with $4 \%$ paraformaldehyde and washed three times with PBS containing $0.1 \%$ Triton X-100. The tissues were embedded in O.C.T (Sakura, Japan) and the embedded block was sectioned using a Cryo-cut microtome (General Data Healthcare, Cincinnati, OH, USA) at 3-4 $\mu \mathrm{m}$ thickness. The sections were stained with the Oil Red O solution. The stained sections were observed under the light microscope (Zeiss Axioskop, Carl Zeiss, Inc., Jena, Germany). Staining area in tissues was evaluated using color-based threshold by Image J program (NIH, Bethesda, MD, USA). The total percentage of the staining area (lipid accumulation) was calculated as the sum of red-stained area divided by total area of microscopic field. Epididymal adipose tissues were fixed with $10 \%$ formalin and embedded in paraffin. The tissue blocks were sectioned at 8-10 $\mu \mathrm{m}$ and slide samples were obtained. The slides were stained with the H\&E solution (Sigma, St. Louis, MO, USA) and observed under the light microscope. Adipocyte size was measured using Image J (NIH, Bethesda, MD, USA).

\subsection{Statistical Analysis}

The experimental data were analyzed using one-way analysis of variance (ANOVA) followed by Tukey's post hoc test (GraphPad PRISM 8, San Diego, USA); $p<0.05$ was considered statistically significant. Data are stated as mean and standard deviation (SD). 


\section{Results}

\subsection{Effects of SME on Proliferation and Differentiation of 3T3-L1 Cells}

To study the effects of SME on adipocyte proliferation, the number of cells were measured to assess the proliferation of 3T3-L1 pre-adipocyte after SME treatment at 50, 100, or $200 \mu \mathrm{g} / \mathrm{mL} 48 \mathrm{~h}$ later. The cell viability was over $80 \%$ under overall SME treatment (Figure 1A). SME treatment at 100 and $200 \mu \mathrm{g} / \mathrm{mL}$ demonstrated a tendency to inhibit cell proliferation of 3T3-L1 in comparison to the cells treated with $50 \mu \mathrm{g} / \mathrm{mL}$ of SME. (Figure 1A). To understand the effects of SME on adipocyte differentiation, the activity of GPDH was determined in 3T3-L1 with SME treatment at 50, 100, or $200 \mu \mathrm{g} / \mathrm{mL}$. GPDH is highly expressed in mature adipocytes and its activity routinely represents adiposity in vitro [26]. SME significantly inhibited the GPDH activity in a dose-dependent manner $(11.42 \%, 20.53 \%$, and $32.05 \%$ reduction with 50,100, and $200 \mu \mathrm{g} / \mathrm{mL}$ of SME treatment, respectively) (Figure 1B). GPDH plays an important role in the anabolic process of triglyceride (TG) formation [27] and accumulation, which are notable physiological markers of adipocyte differentiation [28]. Therefore, the TG content in adipocytes is crucial to understand the anabolic process of adipocytes, such as development and maturation. As expected, TG accumulation was significantly attenuated by $\geq 100 \mu \mathrm{g} / \mathrm{mL}$ of SME treatment (Figure 1C). The attenuation of anabolic outcomes by SME treatment inhibited the differentiation of murine pre-adipocytes. In addition, lipoprotein lipase (LPL) modulated the removal of TG from the serum and its transfer to tissues such as the liver or white adipose tissue (WAT). Furthermore, LPL activity was elevated according to adiposity. SME treatment significantly inhibited LPL activity along with the pattern of TG accumulation (Figure 1D). Collectively, SME treatment inhibited the proliferation and differentiation of 3T3-L1 pre-adipocytes.

A

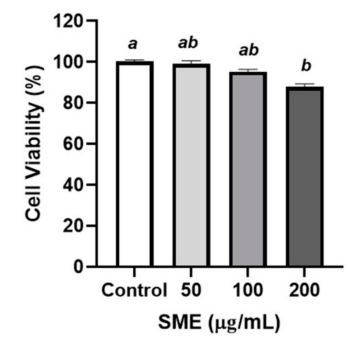

C

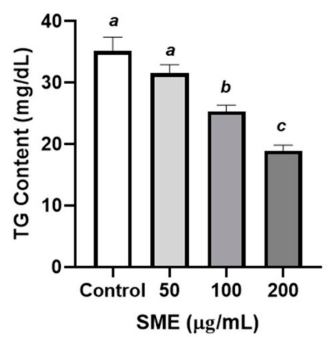

B

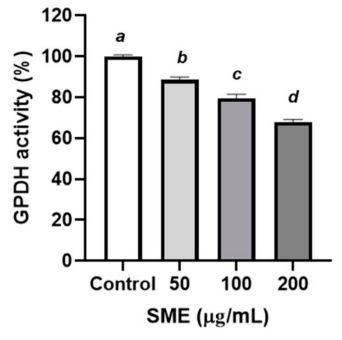

D

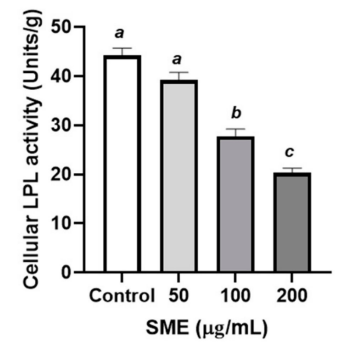

Figure 1. Effects of ethanol extract of Spergularia marina (SME) on proliferation and differentiation of 3T3-L1 cells. The 3T3-L1 pre-adipocytes were treated with SME (50, 100, and $200 \mu \mathrm{g} / \mathrm{mL})$ for $48 \mathrm{~h}$. Dimethyl sulfoxide (DMSO) was used as control. (A) Cell proliferation was determined by 3-(4,5-dimethylthiazol-2-yl)-2,5-diphenyltetrazolium bromide (MTT) assay. (B) Adipocyte differentiation was accessed by glycerol-3-phosphate dehydrogenase (GPDH) measurement (C) Triglyceride (TG) content was determined by manual methods. (D) Lipoprotein lipase (LPL) activity was assayed using the Nilsson-Ehle and Schotz methods. Values are means \pm SDs, $n=3$. Data were analyzed by one-way ANOVA using Kruskal-Wallis analysis followed by Tukey's post hoc test. Labeled means without a common letter differ, $p<0.05$. 


\subsection{Effects of SME on Proliferation and Differentiation of Porcine Pre-Adipocytes}

Based on the results in murine adipocytes, porcine pre-adipocytes were also employed. It is well known that pigs are closer phylogenetically and anatomically to humans in terms of energy metabolism and storage [29]. To examine the effect of SME on the proliferation of porcine pre-adipocytes, porcine pre-adipocytes were treated with SME (50,100, or $200 \mu \mathrm{g} / \mathrm{mL})$. The $200 \mu \mathrm{g} / \mathrm{mL} \mathrm{SME}$ treated group significantly impeded cell proliferation after $48 \mathrm{~h}(-9.62 \%)$ in comparison to the control group (Figure 2A). To investigate the effects of SME treatment on differentiation of porcine pre-adipocytes, the activity of GPDH was measured. SME treatment significantly decreased the activity of GPDH in a dose-dependent manner $(9.13 \%, 16.22 \%$, and $26.73 \%$ reduction with 50,100 , and $200 \mu \mathrm{g} / \mathrm{mL}$ of SME treatments, respectively) (Figure 2B). These results exhibited a similar trend as that observed in murine adipocytes (Figure 1A,B). To test the inhibitory effect of SME on adipogenesis in porcine pre-adipocytes, TG contents and LPL activity were measured. SME treatment significantly inhibited TG accumulation at $\geq 100 \mu \mathrm{g} / \mathrm{mL}$ (Figure 2C). In addition, SME treatment significantly inhibited LPL activity at 100 and $200 \mu \mathrm{g} / \mathrm{mL}$ doses (Figure 2D). Hence, these results indicated that SME inhibited the proliferation and differentiation of porcine pre-adipocytes. SME treatment suppressed adiposity in mammalian adipocytes, both murine and porcine (Figures 1 and 2).

A

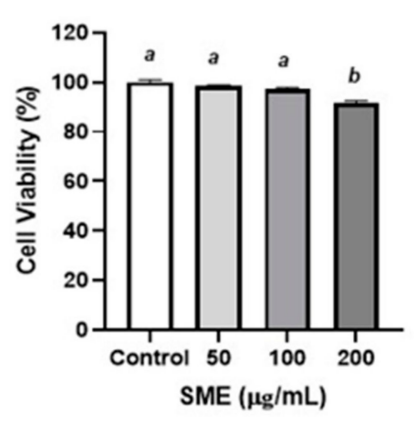

C

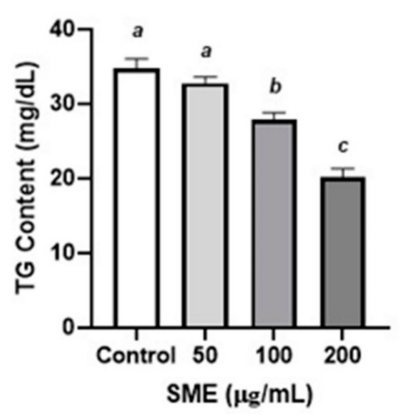

B

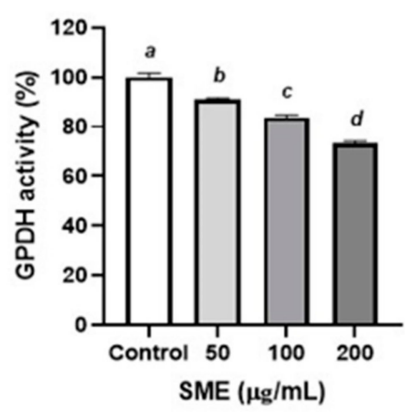

D

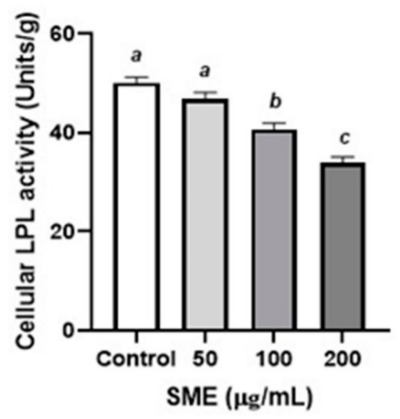

Figure 2. Effects of ethanol extract of Spergularia marina (SME) on proliferation and differentiation of porcine pre-adipocytes. Porcine primary adipocytes were treated with SME (50, 100, and $200 \mu \mathrm{g} / \mathrm{mL}$ ) for $48 \mathrm{~h}$. Dimethyl sulfoxide (DMSO) was used as control. (A) Cell proliferation was determined by 3-(4,5-dimethylthiazol-2-yl)-2,5-diphenyltetrazolium Bromide (MTT) assay. (B) Adipocyte differentiation was accessed by glycerol-3-phosphate dehydrogenase (GPDH) measurement (C) Triglyceride (TG) content was determined by manual methods. (D) Lipoprotein lipase (LPL) activity was assayed using the Nilsson-Ehle and Schotz methods. Values are means \pm SDs, $n=3$. Data were analyzed by one-way ANOVA using Kruskal-Wallis analysis followed by Tukey's post hoc test. Means labeled without a common letter differ, $p<0.05$. 


\subsection{SMP Ameliorated HFD-Induced Obesity}

To evaluate the effect of SM in vivo, a diet-inducible obese model was used in rats. Rats in each group were fed a normal diet (ND, 31\% of calories from fat), a high-fat diet (HFD, $46 \%-48 \%$ of calories from fat), HFD with SMP low supplement (HFD-SL, HFD + 3\% of SMP), or a HFD and with SMP high supplement (HFD-SH, HFD + 5\% of SMP) for 4 weeks. The composition of ND and HFD is described in Table 1. The BW significantly increased in the HFD group compared to the ND group 1, 3, and 4 weeks after HFD feeding (Figure 3). BW gain (the BW difference between the endpoint and the initial point) in the HFD group was significantly greater than in the ND group, and the SMP supplemented groups (HFD-SL and HFD-SH) reported a significant reduction in BW gain (Table 2). The SMP supplement groups (HFD-SL and HFD-SH) demonstrated a significant decrease in food intake, indicating that the observed reduction in BW gain may be due to reduced caloric intake (Table 2). According to the FER assessment, HFD feeding (HFD, HFD-SL, and HFD-SH) demonstrated significantly higher FER levels in comparison to the ND group. However, there were no significant changes induced by the SMP supplement in the HFD-induced obese rats (Table 2). Here, it could be postulated that SMP does not inhibit the increased FER to reduce BW. To examine the weight change in organs in HFD-induced obese rats, the representative metabolic organs, such as liver and several kinds of WATs, were weighed. The liver weight was not altered by dietary intervention with SMP (Table 3). Among the WAT tissues, the weight of the epididymal adipose tissues (EAT) significantly increased in the HFD group compared to the ND group. In addition, perirenal adipose tissue (PAT) increased by HFD feeding without effect of SMP by dietary supplementation. On the other hand, the weight of other adipose tissues, such as mesenteric and retroperitoneal adipose tissues (MAT and RAT), was not significantly altered following the HFD feeding. The total adipose tissue weight demonstrated a significant increase after HFD feeding and reflected the increased EAT and PAT weights (Table 3).

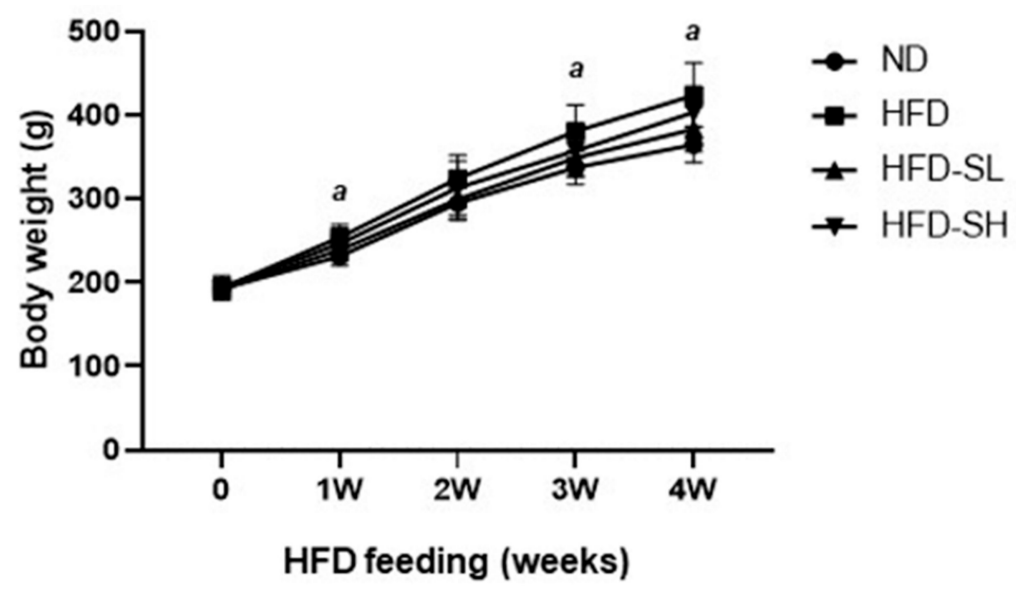

Figure 3. Effect of Spergularia marina powder (SMP) supplementation on body weight gain under high-fat diet (HFD) feeding. Rats were fed a normal diet or high-fat diet with/without the Spergularia marina Griseb powder supplement for 4 weeks. The rat body weights were measured every week. ND, Normal diet; HFD, High-fat diet; HFD-SL, High-fat diet $+3 \%$ of Spergularia marina Griseb; HFD-SH, High-fat diet $+5 \%$ of Spergularia marina Griseb. Values are means \pm SDs, $n=8$. Data were analyzed by one-way ANOVA using Kruskal-Wallis analysis followed by Tukey's post hoc test. ${ }^{\text {a }}$ Different from the other dietary groups at that age, $p<0.05$. 
Table 2. Effects of the Spergularia marina Griseb powder (SMP) on body weight gain, food intake and food efficiency ratio in HFD-induced obese rats.

\begin{tabular}{ccccc}
\hline Group & $\boldsymbol{n}$ & $\begin{array}{c}\text { Body Weight Gain } \\
\text { (g/day) }\end{array}$ & $\begin{array}{c}\text { Food Intake } \\
\text { (g/day) }\end{array}$ & $\begin{array}{c}\text { FER } \\
\text { (Food Efficiency Ratio) }\end{array}$ \\
\hline ND & 8 & $6.16 \pm 0.52^{c}$ & $21.80 \pm 1.24^{a}$ & $0.28 \pm 0.01^{b}$ \\
HFD & 8 & $8.22 \pm 1.30^{a}$ & $20.17 \pm 2.29^{a}$ & $0.41 \pm 0.04^{a}$ \\
HFD-SL (3\%) & 8 & $7.48 \pm 0.69^{\mathrm{b}}$ & $19.03 \pm 1.39^{b}$ & $0.39 \pm 0.03^{a}$ \\
HFD-SH (5\%) & 8 & $6.81 \pm 1.03^{c}$ & $18.55 \pm 1.05^{b}$ & $0.37 \pm 0.04^{a}$ \\
\hline
\end{tabular}

Rats were fed the normal diet or high-fat diet with/without Spergularia marina Griseb powder supplementation 4 weeks. The body weight and food consumption were measured. ND, Normal diet; HFD, High-fat diet; HFD-SL, High-fat diet $+3 \%$ of Spergularia marina Griseb; HFD-SH, High-fat diet $+5 \%$ of Spergularia marina Griseb. Values are means \pm SDs, $n=8$. Data were analyzed by one-way ANOVA using Kruskal-Wallis analysis followed by Tukey's post hoc test. Means labeled without a common letter differ, $p<0.05$.

Table 3. Effects of the Spergularia marina Griseb powder (SMP) on weights of epididymal, mesenteric, retroperitoneal, perirenal, and total adipose tissues (EAT, MAT, RAT, PAT, Total AT) in HFD-induced obese rats.

\begin{tabular}{|c|c|c|c|c|c|c|c|}
\hline Group & $n$ & Liver (g) & EAT (g) & MAT (g) & RAT (g) & PAT (g) & Total AT (g) \\
\hline ND & 8 & $11.03 \pm 1.04$ & $4.50 \pm 1.14^{c}$ & $3.45 \pm 0.96$ & $6.24 \pm 1.46$ & $1.66 \pm 0.32^{b}$ & $15.84 \pm 2.17^{b}$ \\
\hline HFD & 8 & $12.34 \pm 2.70$ & $8.34 \pm 2.70^{a, b}$ & $4.73 \pm 1.25$ & $8.59 \pm 2.12$ & $2.63 \pm 1.08^{a, b}$ & $24.28 \pm 6.40^{a}$ \\
\hline HFD-SL (3\%) & 8 & $11.46 \pm 1.11$ & $5.73 \pm 1.06^{b, c}$ & $4.19 \pm 0.76$ & $7.64 \pm 2.35$ & $2.13 \pm 0.60^{a, b}$ & $19.68 \pm 4.36^{a, b}$ \\
\hline HFD-SH (5\%) & 8 & $11.59 \pm 1.14$ & $7.91 \pm 2.0^{a, b}$ & $4.70 \pm 1.0$ & $8.20 \pm 1.45$ & $2.56 \pm 0.66^{a}$ & $23.36 \pm 4.09^{a}$ \\
\hline
\end{tabular}

Rats were fed the normal diet or high-fat diet with/without Spergularia marina Griseb powder supplementation for 4 weeks. Each adipose tissue was harvested and weighted after washing with PBS. ND, Normal diet; HFD, High-fat diet; HFD-SL, High-fat diet + 3\% of Spergularia marina Griseb; HFD-SH, High-fat diet $+5 \%$ of Spergularia marina Griseb. Values are means $\pm \mathrm{SDs}, n=8$. Data were analyzed by one-way ANOVA using Kruskal-Wallis analysis followed by Tukey's post hoc test. Means labeled without a common letter differ, $p<0.05$.

\subsection{ALT, AST, ALP, and LDH Activities in Serum}

To evaluate the effect of SMP on hepatic functions 4 weeks after HFD feeding in rats, the serum levels of AST, ALT, ALP, and LDH were examined. (Table 4). All values in the HFD group were significantly higher than that in the ND group. Elevated AST levels induced by HFD feeding were significantly inhibited in the SMP supplement groups (HFD-SL and HFD-SH). The elevation of ALT was significantly inhibited in the HFD-SH group compared to the HFD group. Notably, the ALT levels (38.75 U/L) in the HFD-SH group were similar to levels observed in the ND group (30.75 U/L). Collectively, SMP supplementation remarkably decreased hepatic fat accumulation.

Table 4. Effects of the Spergularia marina Griseb powder (SMP) on the liver function.

\begin{tabular}{cccccc}
\hline Group & $\boldsymbol{n}$ & AST (U/L) & ALT (U/L) & ALP (U/L) & LDH (U/L) \\
\hline ND & 8 & $120.50 \pm 20.45^{b}$ & $30.75 \pm 6.84^{b}$ & $650.3 \pm 62.0^{b}$ & $687.1 \pm 116.8^{b}$ \\
HFD & 8 & $189.38 \pm 44.39^{a}$ & $61.75 \pm 4.50^{a}$ & $905.8 \pm 109.5^{a}$ & $888.4 \pm 32.9^{a}$ \\
HFD-SL (3\%) & 8 & $153.38 \pm 31.50^{b}$ & $45.25 \pm 6.65^{a, b}$ & $874.9 \pm 126.2^{a}$ & $804.4 \pm 156.8^{a, b}$ \\
HFD-SH (5\%) & 8 & $136.25 \pm 34.74^{b}$ & $38.75 \pm 4.03^{b}$ & $809.0 \pm 91.0^{b}$ & $736.1 \pm 153.5^{a, b}$ \\
\hline
\end{tabular}

Rats were fed the normal diet or high-fat diet with/without Spergularia marina Griseb powder supplementation for 4 weeks. Aspartate aminotransferase (AST), alanine aminotransferase (ALT), alkaline phosphatase (ALP), and lactate dehydrogenase (LDH) were measured in serum from the experimental rats. ND, Normal diet; HFD, High-fat diet; HFD-SL, High-fat diet $+3 \%$ of Spergularia marina Griseb; HFD-SH, High-fat diet $+5 \%$ of Spergularia marina Griseb. Values are mean $\pm \mathrm{SD}, n=8$. Data were analyzed by one-way ANOVA using Kruskal-Wallis analysis followed by Tukey's post hoc test. Means labeled without a common letter differ, $p<0.05$.

\subsection{Lipids Profiles in Serum}

HFD increases TC and lipid levels and it is one of the leading causes of CVD [30]. To elucidate the risk of metabolic syndrome by HFD-induced obesity, changes in the serum levels of TG, TC, LDL-C, HDL-C, Glu, and AI for atherosclerosis risk and CRF for cardiac dysfunction were assessed in obese rats. The HFD group demonstrated significantly higher levels of TC than the ND group. TC levels 
indicated a trend to decrease following SMP supplementation compared to the HFD group. In the HFD-SH group, the TG level was maintained similar to the level observed in the ND group (Table 5). Increased LDL-C levels in the HFD group were significantly decreased following SMP supplementation in the HFD-SH group. (Table 5). Glu levels were increased by HFD and SMP supplementation (HFD-SL and HFD-SH) inhibited the increased Glu levels in a dose-dependent manner. Based on the lipid profiles, AI and CRF were significantly elevated in the HFD group compared to the ND group; both indexes were significantly decreased with SMP supplementation (HFD-SL and HFD-SH) (Table 5). These data suggested that the SMP supplement improved lipid profiles and CVD risk in the HFD-induced obese rats.

Table 5. Effects of the Spergularia marina Griseb powder (SMP) on the serum lipids profiles in HFD-induced obese rats.

\begin{tabular}{|c|c|c|c|c|c|c|c|c|}
\hline Group & $n$ & $\begin{array}{l}\text { HDL-C } \\
\text { (mg/dL) }\end{array}$ & $\begin{array}{c}\mathrm{TC} \\
(\mathrm{mg} / \mathrm{dL})\end{array}$ & $\begin{array}{c}\text { TG } \\
(\mathrm{mg} / \mathrm{dL})\end{array}$ & $\begin{array}{c}\text { Glu } \\
\text { (mg/dL) }\end{array}$ & $\begin{array}{c}\text { LDL-C } \\
\text { (mg/dL) }\end{array}$ & AI & CRF \\
\hline ND & 8 & $65.13 \pm 9.42^{a}$ & $75.88 \pm 8.66^{b}$ & $64.75 \pm 16.12^{b}$ & $131.5 \pm 16.6^{c}$ & $24.70 \pm 7.08^{c}$ & $0.17 \pm 0.11^{b}$ & $1.17 \pm 0.11^{b}$ \\
\hline HFD & 8 & $47.63 \pm 7.05^{b}$ & $101.63 \pm 12.92^{a}$ & $111.75 \pm 25.08^{a}$ & $179.4 \pm 12.5^{a}$ & $76.35 \pm 12.45^{a}$ & $1.15 \pm 0.24^{a}$ & $2.15 \pm 0.24^{a}$ \\
\hline HFD-SL ( $3 \%)$ & 8 & $51.00 \pm 5.71^{a, b}$ & $85.75 \pm 16.24^{a, b}$ & $76.25 \pm 8.41^{a, b}$ & $159.3 \pm 11.5^{a, b}$ & $50.00 \pm 20.02^{a, b}$ & $0.71 \pm 0.43^{b}$ & $1.71 \pm 0.43^{b}$ \\
\hline HFD-SH (5\%) & 8 & $54.25 \pm 13.13^{a, b}$ & $77.88 \pm 10.62^{a, b}$ & $65.63 \pm 13.79^{b}$ & $148.9 \pm 9.3^{b, c}$ & $36.75 \pm 18.81^{b, c}$ & $0.51 \pm 0.42^{b}$ & $1.51 \pm 0.42^{b}$ \\
\hline
\end{tabular}

Rats were fed the normal diet or high-fat diet with/without Spergularia marina Griseb powder supplementation for 4 weeks. Serum levels of HDL-C, High-density lipoprotein cholesterol; TC, total cholesterol; TG, triglyceride; Glu, glucose; LDL-C, low-density lipoprotein cholesterol; AI, atherogenic index; CRF and cardiac risk factor were measured after isolation of serum from rats. ND, Normal diet; HFD, High-fat diet; HFD-SL, High-fat diet $+3 \%$ of Spergularia marina Griseb; HFD-SH, High-fat diet $+5 \%$ of Spergularia marina Griseb. Values are means \pm SDs, $n=8$. Data were analyzed by one-way ANOVA using Kruskal-Wallis analysis followed by Tukey's post hoc test. Means labeled without a common letter differ, $p<0.05$.

\subsection{TG and TC Levels in Liver and WAT}

Next, we measured TG and TC levels in the liver and WAT of HFD-induced obese rats. In the liver tissue, TG and TC levels were increased in the HFD group compared to the ND group. The lower supplement of SMP (HFD-SL) significantly decreased hepatic TG levels (Table 6). TG and TC levels in EAT and MAT increased under HFD feeding; dietary intervention with SMP significantly inhibited TG accumulation in the HFD-SL group in EAT (Table 6). In addition, the high dose supplement of SMP (HFD-SH) significantly reduced TG and TC levels in MAT (Table 6).

Table 6. Effects of the Spergularia marina Griseb powder (SMP) on the lipids in liver and adipose tissues.

\begin{tabular}{cccccccc}
\hline Group & $\boldsymbol{n}$ & $\begin{array}{c}\text { Liver TG } \\
(\mathbf{m g} / \mathbf{g})\end{array}$ & $\begin{array}{c}\text { Liver TC } \\
(\mathbf{m g} / \mathbf{g})\end{array}$ & $\begin{array}{c}\text { EAT TG } \\
\mathbf{( m g / g )}\end{array}$ & $\begin{array}{c}\text { EAT TC } \\
(\mathbf{m g} / \mathbf{g})\end{array}$ & $\begin{array}{c}\text { MAT TG } \\
(\mathbf{m g} / \mathbf{g})\end{array}$ & $\begin{array}{c}\text { MAT TC } \\
(\mathbf{m g} / \mathbf{g})\end{array}$ \\
\hline ND & 8 & $25.8 \pm 3.8^{c}$ & $82.8 \pm 10.0^{b}$ & $88.2 \pm 8.3^{c}$ & $75.3 \pm 12.9^{c}$ & $35.5 \pm 2.5^{c}$ & $25.3 \pm 3.9^{c}$ \\
HFD & 8 & $60.0 \pm 12.7^{a}$ & $107.9 \pm 18.4^{a}$ & $107.3 \pm 12.2^{a}$ & $125.4 \pm 15.5^{a}$ & $62.7 \pm 2.7^{a}$ & $39.8 \pm 4.5^{a}$ \\
HFD-SL (3\%) & 8 & $45.0 \pm 12.7^{a, b}$ & $98.0 \pm 11.7^{b}$ & $92.3 \pm 4.7^{b, c}$ & $103.7 \pm 16.2^{a, b}$ & $44.3 \pm 3.6^{a, b}$ & $32.2 \pm 4.5^{a, b}$ \\
HFD-SH (5\%) & 8 & $41.0 \pm 7.4^{b, c}$ & $97.6 \pm 11.7^{b}$ & $97.0 \pm 13.5^{a, b}$ & $93.5 \pm 6.4^{b, c}$ & $42.4 \pm 4.5^{b, c}$ & $29.5 \pm 2.7^{b, c}$ \\
\hline
\end{tabular}

Rats were fed the normal diet or high-fat diet with/without Spergularia marina Griseb powder supplementation for 4 weeks. Triglycerides (TG) and total cholesterol (TC) were analyzed from the liver, epididymal adipose tissues (EAT) and mesenteric adipose tissues (MAT). ND, Normal diet; HFD, High-fat diet; HFD-SL, High-fat diet $+3 \%$ of Spergularia marina Griseb; HFD-SH, High-fat diet $+5 \%$ of Spergularia marina Griseb. Values are means \pm SDs, $n=8$. Data were analyzed by one-way ANOVA using Kruskal-Wallis analysis followed by Tukey's post hoc test. Means labeled without a common letter differ, $p<0.05$.

\subsection{Histological Analysis in Liver and Epididymal Adipose Tissues}

To determine the lipid accumulation levels in the liver tissue histologically, Oil Red O staining was performed. Notably, the SMP supplemented groups (HFD-SL, HFD-SH) demonstrated inhibited lipid accumulation in the liver tissues in comparison to the HFD group (Figure 4). The EAT samples were stained with $H \& E$ staining to measure cell size; the cells were observed under the microscope and analyzed using an image analyzer (Figure 5A). Histological analysis of adipose tissues in the HFD group demonstrated a larger cell size in EATs than that of the ND group. In a dose-dependent manner, the SMP supplemented groups demonstrated a decreased adipocyte size compared to the 
HFD group (Figure 5B). Hence, the results suggested that reduced BW gain could be attributed to the decreased fat accumulation in the adipocytes [31]. Furthermore, the results indicated that SMP supplementation could improve the lipid profiles in the serum, liver, and adipose tissue, and could decrease lipid accumulation in the liver and adipose tissues.

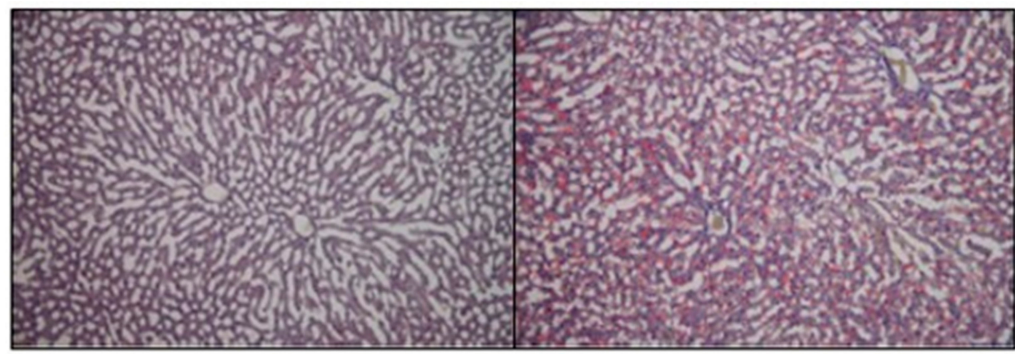

ND

HFD

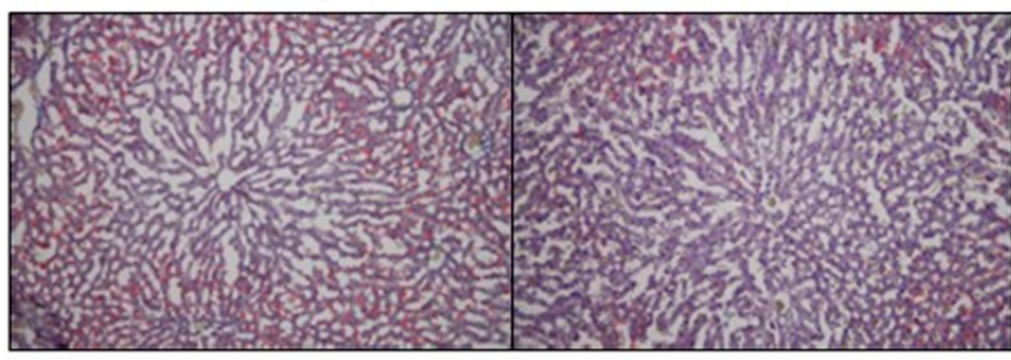

HFD-SL

HFD-SH

(A)

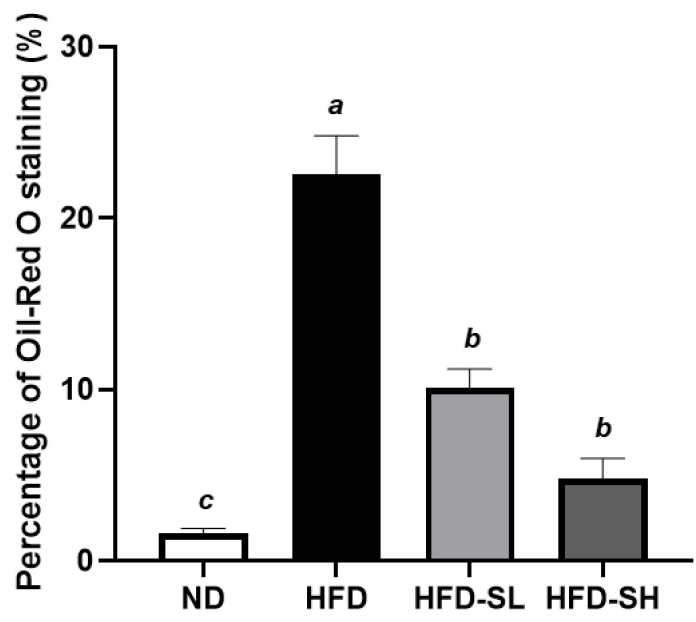

(B)

Figure 4. Effect of Spergularia marina powder (SMP) supplementation on lipid accumulation in the liver. Livers from each experimental group were harvested, fixed, and stained with Oil Red O. ND, Normal diet; HFD, High-fat diet; HFD-SL, High-fat diet $+3 \%$ of Spergularia marina Griseb; HFD-SH, High-fat diet $+5 \%$ of Spergularia marina Griseb. HFD induces numerous and larger lipid droplets; SMP supplementation inhibits lipid accumulation. (A) Representative figures from each group. (B) The quantification of A. Values are means \pm SDs, $n=8$. Data were analyzed by one-way ANOVA using Kruskal-Wallis analysis followed by Tukey's post hoc test. Means labeled without a common letter differ, $p<0.05$. 

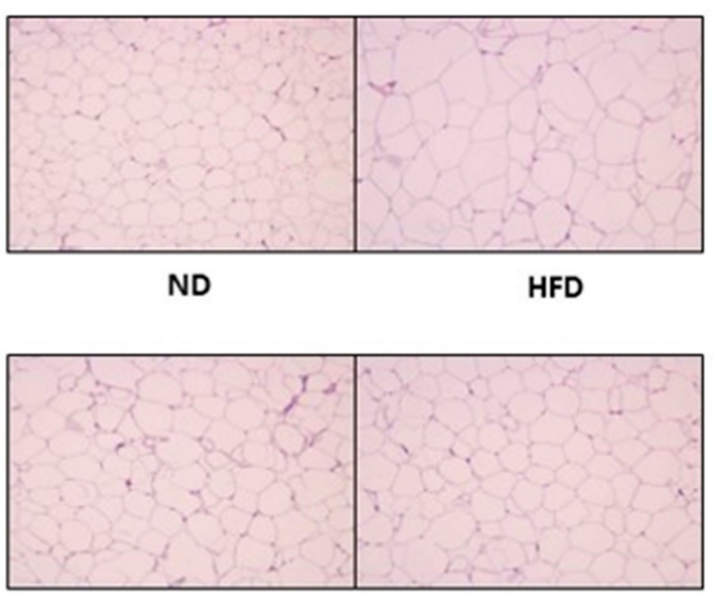

HFD-SL

HFD-SH

(A)

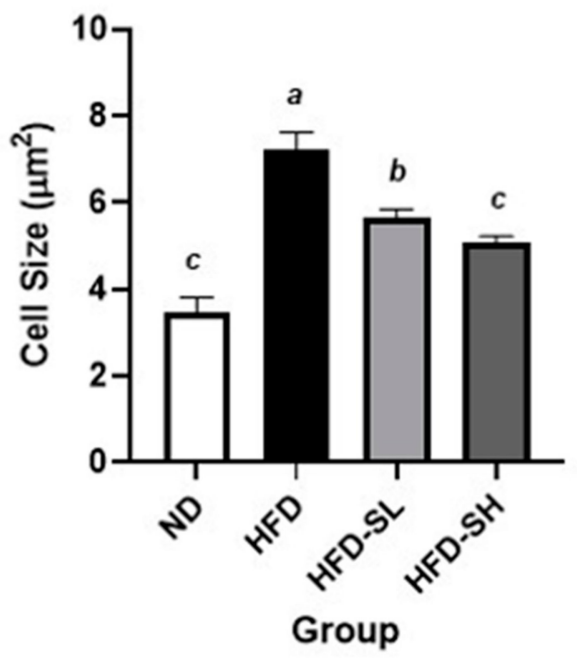

(B)

Figure 5. Histological analysis of epididymal adipose tissue (EAT). Rats were fed the normal diet or high-fat diet with/without Spergularia marina Griseb powder supplementation for 4 weeks. EAT was stained with H\&E. Magnification, 100x. The surface area of EAT was measured using the Image J program. ND, Normal diet; HFD, High-fat diet; HFD-SL, High-fat diet $+3 \%$ of Spergularia marina Griseb; HFD-SH, High-fat diet $+5 \%$ of Spergularia marina Griseb. (A) Representative figures from each group. (B) The quantification of A. Values are means \pm SDs, $n=8$. Data were analyzed by one-way ANOVA using Kruskal-Wallis analysis followed by Tukey's post hoc test. Means labeled without a common letter differ, $p<0.05$.

\section{Discussion}

Obesity is the induced hyperplasia and/or hypertrophy of adipocytes [9]. Hyperplasia of adipocytes is regulated by the proliferation and differentiation of cells, whereas hypertrophy of adipocytes is controlled by the balance between lipogenesis and lipolysis [10]. To elucidate the underlying mechanism and the treatment of obesity, it is crucial to investigate lipid accumulation and lipolysis in cells. The 3T3-L1 cell line used in the current study is the most widely used for evaluating antiobesity activity [32]. Therefore, the study of adipogenesis in 3T3-L1 is important to understand obesity. Furthermore, the regulation of adipogenesis can be one strategy in the treatment and management of obesity. 
Halophytes are salt-tolerant plants growing in saline environments and can be found on the western coast of the Korean peninsula. Reportedly, halophytes are known to have various secondary metabolism and adaptive mechanisms against severe environments, such as salt stress, compared to terrestrial plants [33]. Additionally, halophytes contain a high content of essential minerals, amino acids, phenolic acids, and flavonoids [14]. Several species of Spergularia have been examined and have reported beneficial effects on human health. These beneficial effects include antidiabetic [16], hypoglycemic [34], diuretic [35], and cholesterol-lowering [36] effects. For decades, Spergularia marina ('Sebalnamul' in Korean), a local food preference in South Korea, has been regarded as a nutritious source of amino acids, vitamins, and minerals; however, few studies have investigated the regulated physiological factors in vitro and in vivo [37-39].

The present study, for the first time, demonstrated that SME induced a significant inhibition of 3T3-L1 adipocyte proliferation, differentiation, lipid accumulation, and lipolysis (Figure 1). Furthermore, while 3T3-L1 pre-adipocytes are a widely accepted model for obesity research, their results cannot be sufficiently and directly extrapolated to human physiology, given the physiological and metabolic differences between species [18]. Porcine pre-adipocytes are a superior model for the study of adipogenesis and obesity-related diseases compared to rodent cell models owing to their higher similarity to human cells [40]. Hence, primary cultures of porcine pre-adipocytes have served as a useful tool for investigating pre-adipocyte proliferation and differentiation [29]. We performed adipocyte proliferation and differentiation and assessed TG accumulation using porcine pre-adipocytes. With regards to cell proliferation, differentiation, TG accumulation and lipolysis, SME demonstrated a similar trend to the results observed in the 3T3-L1 cells. (Figure 2). GPDH is an enzyme that converts dehydroxyacetone phosphate to glycerol-3-phosphate and is useful to investigate the differentiation of pre-adipocytes into mature adipocytes [41]. In this study, treatment with different concentrations of SMEs inhibited the GPDH acidity in 3T3-L1 cells and porcine pre-adipocytes in a dose-dependent manner (Figures 1B and 2B). The decreased TG accumulation demonstrated with SME treatment in adipocytes (Figures $1 \mathrm{C}$ and $2 \mathrm{C}$ ) reflected the less differentiated adipocytes. LPL is an important enzyme in regulating lipid accumulation and lipid mobilization and is expressed early during the differentiation of the cell [42]. Consistently, LPL activities in adipocytes (Figures 1D and 2D) were reduced with the treatment of 100 and $200 \mu \mathrm{g} / \mathrm{mL}$ SME. Similarly, the ethanolic extract (50\%) from Salsola komarovi inhibited TG accumulation in a dose-dependent manner [43]. Kim et al. reported that 3T3-L1 cells treated with polymannuronate extracted from Phaephycease (brown algae) showed a reduction in GPDH activity and inhibited adipocyte differentiation [44]. The measurement of the TG content in cells is one method to evaluate differentiation of adipocyte [45]. Collectively, these results suggest that SME may block mammalian adipogenesis.

HFD induced lipid accumulation in the liver, resulting in liver weight gain [46], and it is well known that HFD induces an increase in WAT weight. The liver is the main organ to play an important role in lipoprotein biosynthesis and distribution [47]. In this study, HFD did not increase the weight of the liver tissue. Additionally, SMP supplementation did not significantly regulate liver tissue weight (Table 3). Hepatic TG and TC levels were significantly increased in the HFD group compared to the ND group. Hepatic TG levels were significantly reduced in the HFD-S groups compared to the HFD group (Table 6). The decreased TG contents were confirmed by the observation of smaller lipid droplets in the liver tissue following the supplementation of SMP (HFD-SL, HFD-SH) (Figure 4). Therefore, SM might play a protective role in the liver by inhibiting excessive lipid accumulation. Among adipose tissues, EAT weight was significantly reduced in the HFD-SL group in comparison to the HFD group (Table 3). Similarly, we observed that the HFD group demonstrated higher TG and TC levels in EAT and MAT compared to the ND group. TG levels in EAT showed a tendency to reduce in the HFD-SL group compared to the HFD group, with the higher SMP supplement reducing the levels of TC in EAT (Table 6). Furthermore, the higher supplement of SMP (HFD-SH) prevented the elevation of TG and TC levels in MAT induced by HFD feeding. The increased size of adipocytes in the HFD-induced obese rats indicates that the accumulation of TG in adipocytes was due to the consumption of HFD. 
Adipocyte size measurement is one of the methods to assess obesity [48]. In this study, adipocyte size in WAT significantly decreased with SMP supplementation under HFD feeding, implying that adipocyte hypertrophy was prevented due to the inhibition of TG accumulation (Figure 5). These results suggested that ameliorated obesity by SM could be attributed to the reduced adiposity in WAT, resulting in improved lipid accumulation. Relatively higher contents of dietary fiber in SMP $(4.45 \%$; data not shown) supplementation may attenuate systemic and peripheral fat accumulation markedly against high fat consumption in rodents. Recent reports addressed that enriched fiber consumption was also effective to decrease systemic and hepatic lipids levels significantly against dietary high fat consumption in mammals [49,50].

Serum ALT and AST are enzymatic markers of liver damage from fatty liver caused by HFD, high cholesterol diet, and alcohol, or damage of liver tissue. These pathological conditions accelerate the release of these enzymes into the blood, leading to higher activities [51]. The current results showed that the SMP supplement reduced ALT and AST activities in serum from the HFD-induced obese rats (Table 4). In addition, LDH is an enzyme involved in the oxidation-reduction reaction at the final step of anaerobic glycolysis in the cell. It has been reported that LDH activity markedly increased in acute hepatitis, early liver cancer, myocardial infarction, pernicious anemia, and leukemia [52]. In this study, in serum LDH activity elevated by HFD, a decreased trend was observed in the SMP-supplemented groups. Abdominal adiposity is strongly related to insulin resistance, impaired glucose metabolism, eventually leading to the development of type 2 diabetes mellitus (T2DM) [53]. Therefore, we measured blood glucose in this setting and observed that the blood glucose level was significantly increased following HFD feeding. Notably, the SMP supplement reduced glucose levels in a dose-dependent manner (Table 5). This indicates that HFD feeding increased the risk of metabolic syndrome and possibly diabetes. However, to ascertain results, insulin resistance should be carefully evaluated; one of the representative methodologies is the oral glucose tolerance test (OGTT) [54].

HDL-C and LDL-C are lipoproteins that play a role in the transfer of cholesterol. HDL-C is considered beneficial because it removes excess cholesterol from tissues and carries it to the liver for disposal. Dyslipidemia is characterized by elevated plasma cholesterol, especially increased LDL-C levels. In contrast to HDL-C, LDL-C is undesirable as it deposits the excess cholesterols in blood vessels, inducing and contributing to cardiovascular disease [55]. In addition, the accumulation of abdominal fat demonstrates higher TG levels in blood [56]. In this study, SMP supplementation indicated a tendency to increase HDL-C, compared to the HFD group, but was not statistically significant. On the other hand, LDL-C was inhibited in SMP supplemented groups in comparison to the HFD group (Table 5).

There are several reports using halophytes to treat HFD-induced obesity and metabolic diseases. Salicornia herbacea L. (glasswort) [57-59], Salsola komarovi [34], Salicornia herbacea L. [60], Limonium tetragonum [61], Oenanthe javanica [62], and Nitraria retusa [63] reported antiobesity effects on BW reduction and improved serum lipids profiles. In addition, Salicornia herbacea L. was reported that a high cholesterol diet resulted in a significant elevation of serum ALT and AST activities. Notably, the enzymatic hydrolysate of glasswort decreased ALT activity [64]. These data further illustrate the efficacy of halophytes as physiological functional food.

Previously, it has been reported that the decrease in serum lipids (TG, TC, and LDL-C) reduced the risk of CVD. It is well documented that the metabolic syndrome is associated with an increased risk of all-cause mortality and CVD [65]. In this study, we observed that SMP supplementation improved AI and CRF (Table 5), implying that the supplement could be a preventive treatment in metabolic-syndrome-related CVD. Hence, it is essential to measure cardiac function by performing echocardiography along with histological evaluations [66]. In addition, we need further studies as to whether SM treatment could attenuate the size of fully differentiated adipocyte and relevant metabolic complications to evaluate the effects of SMP in adulthood obesity since, in this study, we mainly focused the antiadipogenic effect of SM. Moreover, in our settings, we could not clearly demonstrate the potential toxicity of SM due to the absence group assignment for ND with SMP. However, we assume 
that SM is generally a safe material since Kim et al. reported that SM has significant, remarkable radical scavenging effects in murine adipocytes at the concentration of $100 \mu \mathrm{g} / \mathrm{mL}$ [37]. Additionally, Fatih Karadeniz et al. reported that SME treatment into pre-osteoblasts did not cause cytotoxicity at the concentration of $100 \mu \mathrm{g} / \mathrm{mL}$ [67]. Moreover, in our experimental animals, hepatic AST and ALT, which are elevated in toxic responses, were significantly suppressed in SMP supplementation against HFD-fed rats. Therefore, we logically postulate that SM, a traditionally edible food in Korea, may be considered as a relatively safe material in our experimental setting. Collectively, the current research proved the effects of SM, a kind of halophyte, as an antiobesity agent. Furthermore, SM improves the lipid profile and could alleviate the metabolic syndrome, including the risk of CVD.

\section{Conclusions}

This study investigated the antiobesity effects of SM in vitro and in vivo. SM exhibited antiobesity effects by modulating adipogenesis and lipolysis in the animal study. Our data suggested that Spergularia marina Griseb could have a favorable role in lipid metabolism in the serum, liver, and adipose tissue and may decrease the accumulation of TG.

Author Contributions: Conceptualization, Y.-H.P., J.-J.L. and J.-H.H.; methodology, Y.-H.P., J.-J.L., H.-K.S. and J.B.; software, H.-K.S. and J.B.; validation, Y.-H.P., J.-J.L., H.-K.S., J.B., B.-H.K. and J.-H.H.; formal analysis, H.-K.S. and J.B.; investigation, J.-J.L., H.-K.S., J.B. and J.-H.H.; resources, Y.-H.P. and J.-J.L.; data curation, Y.-H.P., J.-J.L., H.-K.S., J.B. and J.-H.H.; writing-original draft preparation, Y.-H.P., J.-J.L., H.-K.S., J.B., B.-H.K. and J.-H.H.; writing-review and editing, J.-J.L., H.-K.S., J.B. and J.-H.H.; visualization, H.-K.S., J.B. and J.-H.H.; supervision, J.-J.L. and J.-H.H.; project administration, J.-J.L. and J.-H.H.; funding acquisition, Y.-H.P. and J.-J.L. All authors have read and agreed to the published version of the manuscript.

Funding: This research received no external funding.

Conflicts of Interest: The authors declare no conflict of interest.

\section{References}

1. Bjorntorp, P. The associations between obesity, adipose tissue distribution and disease. Acta Med. Scand. Suppl. 1988, 723, 121-134. [CrossRef] [PubMed]

2. Ministry of Health and Welfare. Korea Health Statistics 2014 Korean National Health and Nutrition Examination Survey; Korea Centers for Disease Control and Prevention: Seoul, Korea, 2014.

3. World Health Organization. Global status report on noncommunicable disease 2014. Geneva: WHO Global Strategy on Diet, Physical Activity and Health. 2015. Available online: http://www.who.int/mediacentre/ factsheets/fs311/en/ (accessed on 10 December 2019).

4. Albu, J.; Allison, D.; Boozer, C.D.; Heymsfield, S.; Kissileff, H.; Kretser, A.; Krumhar, K.; Leibel, R.; Nonas, C.; Pi-Sunyer, X.; et al. Obesity solutions: report of a meeting. Nutr. Rev. 1997, 55, 150-156. [CrossRef] [PubMed]

5. Jun, J.E.; Choi, Y.J.; Lee, Y.H.; Kim, D.J.; Park, S.W.; Huh, B.H.; Lee, E.J.; Jee, S.H.; Hur, K.Y.; Choi, S.H.; et al. ApoB/ApoA-I ratio is independently associated with carotid atherosclerosis in type 2 diabetes mellitus with well-controlled LDL cholesterol levels. Korean J. Intern. Med. 2018, 33, 138-147. [CrossRef] [PubMed]

6. Gwag, B.J.; Lee, Y.A.; Ko, S.Y.; Lee, M.J.; Im, D.S.; Yun, B.S.; Lim, H.R.; Park, H.R.; Byun, H.R.; Son, S.J.; et al. Marked prevention of ischemic brain injury by Neu2000, an NMDA antagonist and antioxidant derived from aspirin and sulfasalazine. J. Cereb. Blood Flow Metab. 2007, 27, 1142-1151. [CrossRef]

7. Mokdad, A.H.; Bowman, B.A.; Ford, E.S.; Vinicor, F.; Marks, J.S.; Koplan, J.P. The continuing epidemics of obesity and diabetes in the United States. JAMA 2001, 286, 1195-1200. [CrossRef]

8. Rosen, E.D.; Spiegelman, B.M. Molecular regulation of adipogenesis. Annu. Rev. Cell Dev. Biol. 2000, 16, 145-171. [CrossRef]

9. Gesta, S.; Tseng, Y.H.; Kahn, C.R. Developmental origin of fat: tracking obesity to its source. Cell 2007, 131, 242-256. [CrossRef]

10. Roncari, D.A.; Lau, D.C.; Kindler, S. Exaggerated replication in culture of adipocyte precursors from massively obese persons. Metabolism 1981, 30, 425-427. [CrossRef]

11. Weigle, D.S. Pharmacological therapy of obesity: past, present, and future. J. Clin. Endocrinol. Metab. 2003, 88, 2462-2469. [CrossRef] 
12. Yun, J.W. Possible anti-obesity therapeutics from nature-a review. Phytochemistry 2010, 71, $1625-1641$. [CrossRef]

13. Heo, B.G.; Park, Y.J.; Park, Y.S.; Hee, I.M.; Cho, J.Y. Distribution status, physicochemical composition, and physiological activity of Spergularia marina cultivated. Korean J. Community Living Sci. 2009, 20, 181-191.

14. Kim, M.S. Isolation and structural elucidation of antioxidants from Spergularia marina Griseb. Master's Thesis, Chonnam National University, Gwangju, Korea, 2013.

15. Lee, J.J.; Jung, H.O. Changes in physicochemical properties of Spergularia marina Griseb by blanching. Korean J. Food Preserv. 2012, 19, 866-872. [CrossRef]

16. Cho, J.Y.; Huang, Z.; Park, S.Y.; Park, K.H.; Pai, T.K.; Kim, S.Y.; Kim, H.R.; Ham, K.S. The effects of several halophytes on insulin resistance in Otsuka long-evans tokushima fatty rats. Korean. J. Food Sci. Technol. 2014, 46, 100-107. [CrossRef]

17. Chen, C.L.; Brodie, A.E.; Hu, C.Y. CCAAT/enhancer-binding protein beta is not affected by tetrachlorodibenzo-p-dioxin (TCDD) inhibition of 3T3-L1 preadipocyte differentiation. Obes. Res. 1997, 5 , 146-152. [CrossRef] [PubMed]

18. Bohan, A.E.; Purvis, K.N.; Bartosh, J.L.; Brandebourg, T.D. The proliferation and differentiation of primary pig preadipocytes is suppressed when cultures are incubated at 37 degrees Celsius compared to euthermic conditions in pigs. Adipocyte 2014, 3, 322-332. [CrossRef]

19. Wise, L.S.; Green, H. Participation of one isozyme of cytosolic glycerophosphate dehydrogenase in the adipose conversion of 3T3 cells. J. Biol. Chem. 1979, 254, 273-275.

20. Nilsson-Ehle, P.; Garfinkel, A.S.; Schotz, M.C. Intra- and extracellular forms of lipoprotein lipase in adipose tissue. Biochim. Biophys. Acta 1976, 431, 147-156. [CrossRef]

21. Friedewald, W.T.; Levy, R.I.; Fredrickson, D.S. Estimation of the concentration of low-density lipoprotein cholesterol in plasma, without use of the preparative ultracentrifuge. Clin. Chem. 1972, 18, 499-502. [CrossRef]

22. Rosenfeld, L. Lipoprotein analysis. Early methods in the diagnosis of atherosclerosis. Arch. Pathol. Lab. Med. 1989, 113, 1101-1110.

23. Folch, J.; Lees, M.; Sloane Stanley, G.H. A simple method for the isolation and purification of total lipides from animal tissues. J. Biol. Chem. 1957, 226, 497-509.

24. Biggs, H.G.; Erikson, J.M.; Moorehead, W.R. A manual colormetric assay of triglycerides in serum. Clin. Chem. 1975, 21, 437-441. [CrossRef] [PubMed]

25. Zlatkis, A.; Zak, B. Study of a new cholesterol reagent. Anal Biochem. 1969, 29, 143-148. [CrossRef]

26. Sottile, V.; Seuwen, K. A high-capacity screen for adipogenic differentiation. Anal Biochem. 2001, 293, 124-128. [CrossRef] [PubMed]

27. Hsu, C.L.; Yen, G.C. Effects of flavonoids and phenolic acids on the inhibition of adipogenesis in 3T3-L1 adipocytes. J. Agric. Food Chem. 2007, 55, 8404-8410. [CrossRef] [PubMed]

28. MacDougald, O.A.; Lane, M.D. Transcriptional regulation of gene expression during adipocyte differentiation. Annu. Rev. Biochem. 1995, 64, 345-373. [CrossRef] [PubMed]

29. Spurlock, M.E.; Gabler, N.K. The development of porcine models of obesity and the metabolic syndrome. J. Nutr. 2008, 138, 397-402. [CrossRef]

30. Di Renzo, D.; Owens, G.K.; Leeper, N.J. "Attack of the Clones": Commonalities Between Cancer and Atherosclerosis. Circ. Res. 2017, 120, 624-626. [CrossRef]

31. Maclean, P.S.; Bergouignan, A.; Cornier, M.A.; Jackman, M.R. Biology's response to dieting: the impetus for weight regain. Am. J. Physiol. Regul. Integr. Comp. Phys. 2011, 301, R581-R600. [CrossRef]

32. Green, H.; Meuth, M. An established pre-adipose cell line and its differentiation in culture. Cell. 1974, 3, 127-133. [CrossRef]

33. Park, J.C.; Choi, J.W. Screening of marine natural products on inhibitory effect ofb the formation of lipid peroxidation. Kor. J. Pharmacogn. 1996, 27, 117-122.

34. Cheong, J.H. Characteristics of seed germination in halophyte influenced by temperature. Master's Thesis, Mokpo National University, Mokpo, Korea, 2011.

35. Lee, H.J.; Kim, Y.A.; Ahn, J.W.; Lee, B.J.; Moon, S.G.; Seo, Y. Screening of peroxynitrite and DPPH radical scavenging activities from salt marsh plants. Korean J. Biotechnol. Bioeng. 2004, 19, 57-61.

36. Kim, J.B.; Choe, S.N.; Choe, K.H.; Lim, S.H.; Chai, S.J. Functional components of halophyte-Antioxidant substances in Salicornia herbacea L. J. Fish. Mar. Sci. Educ. 2007, 19, 197-205. 
37. Kim, H.S.; Kim, J.A.; Karadeniz, F.; Ahn, B.N.; Kong, C.S. Radical scavenging and anti-inflammatory effects of the halophyte Spergularia marina Griseb. J. Biosci. 2014, 69, 425-433.

38. Kim, K.; Lee, Y.M.; Rhyu, M.R.; Kim, H.Y. Spergularia marina induces glucagon-like peptide-1 secretion in NCI-H716 cells through bile acid receptor activation. J. Med. Food. 2014, 17, 1197-1203. [CrossRef] [PubMed]

39. Park, Y.H. Effects of Spergularia marina Griseb. powder on adipocytes and high-fat diet-induced obese rats. Ph.D. Thesis, Chosun University, Gwangju, Korea, 2016.

40. Pang, W.; Wang, Y.; Wei, N.; Xu, R.; Xiong, Y.; Wang, P.; Shen, Q.; Yang, G. Sirt1 inhibits akt2-mediated porcine adipogenesis potentially by direct protein-protein interaction. PLoS ONE 2013, 8, e71576. [CrossRef] [PubMed]

41. Kim, J.Y. Effect of resveratrol and peanut sprout extracts on cell proliferation and lipid accumulation in mouse fibroblast 3T3-L1 preadipocytes. Master's Thesis, Dankook University, Cheonan, Korea, 2011.

42. Boone, C.; Gregoire, F.; Remacle, C. Culture of porcine stromal-vascular cells in serum-free medium: Differential action of various hormonal agents on adipose conversion. J. Anim. Sci. 2000, 78, 885-895. [CrossRef] [PubMed]

43. Lee, Y.S. Studies on the bioactivities of Salsola komarovi extract. Master's Thesis, Wonkwang University, Iksan, Korea, 2015.

44. Kim, I.H.; Nam, T.J. The effects of polymannuronates on leptin in 3T3-L1 adipocytes. J. Kor. Fih. Soc. 2004, 37, 372-379. [CrossRef]

45. Cha, S.Y.; Jang, J.Y.; Lee, Y.H.; Lee, G.Y.; Lee, H.J.; Hwang, K.T.; Kim, Y.J.; Jun, Y.J.; Lee, J.M. Lipolytic effect of methanol extracts from Luffa cylindrica in mature 3T3-L1 adipocytes. J. Korean Soc. Food Sci. Nutr. 2010, 39, 813-819. [CrossRef]

46. Sung, N.J.; Lee, S.J.; Shin, J.H.; Chung, M.J.; Lim, S.S. Effects of Houttuynia cordata Thunb powder and juice on lipid composition of liver, brain and kidney in dietary hypercholesterolemic rats. J. Korean Soc. Food Sci. Nutr. 1998, 27, 1230-1235.

47. Frizell, E.; Liu, S.L.; Abraham, V.; Ozaki, I.; Eghbali, M.; Sage, E.H.; Zern, M.A. Expression of SPARC in normal and fibrotic livers. Hepatology 1995, 21, 847-854.

48. Kim, H.S.; Kim, T.W.; Kim, D.J.; Hwang, H.J.; Lee, H.J.; Cheo, M. Effects of natural plants supplementation on adipocyte size of the epididymal fat pads in rat. J. Korean Soc. Food Sci. Nutr. 2007, 36, 419-423. [CrossRef]

49. Zhai, X.; Lin, D.; Zhao, Y.; Li, W.; Yang, X. Effects of Dietary Fiber Supplementation on Fatty Acid Metabolism and Intestinal Microbiota Diversity in C57BL/6J Mice Fed with a High-Fat Diet. J. Agric. Food Chem. 2018, 66, 12706-12718. [CrossRef] [PubMed]

50. Li, Q.; Liu, F.; Liu, J.; Liao, S.; Zou, Y. Mulberry Leaf Polyphenols and Fiber Induce Synergistic Antiobesity and Display a Modulation Effect on Gut Microbiota and Metabolites. Nutrients 2019, 11, 1674. [CrossRef] [PubMed]

51. Plaza, G.L.; Charbonneau, M. Detection and evaluation of chemically induced liver injury. In Hayes' Principles and Methods of Toxicology, 5th ed.; CRC Prress: Boca Raton, FL, USA, 1994; Chapter 29; pp. 1465-1507.

52. Lee, S.H.; Park, Y.B.; Choi, M.S. The effect of dietary citrus flavonoid supplementation on cholesterol biosynthesis control in rats. In The Autumnal Symposium of Korean Nutrition Association; Korean Nutrition Association: Seoul, Korea, 1998; Volume 79.

53. Moreno-Fernandez, S.; Garces-Rimon, M.; Vera, G.; Astier, J.; Landrier, J.F.; Miguel, M. High Fat/High Glucose Diet Induces Metabolic Syndrome in an Experimental Rat Model. Nutrients 2018, 10, 1502. [CrossRef] [PubMed]

54. Srinivasan, K.; Viswanad, B.; Asrat, L.; Kaul, C.L.; Ramarao, P. Combination of high-fat diet-fed and low-dose streptozotocin-treated rat: a model for type 2 diabetes and pharmacological screening. Pharmacol Res. 2005, 52, 313-320. [CrossRef]

55. Davignon, J.; Cohn, J.S. Triglycerides: a risk factor for coronary heart disease. Atherosclerosis. 1996, 124, S57-S64. [CrossRef]

56. Lee, J.J.; Park, M.R.; Kim, A.R.; Lee, M.Y. Effects of ramie leaves on improvement of lipid metabolism and anti-obesity effect in rats fed a high fat/high cholesterol diet. Korean J. Food Sci. Technol. 2011, 43, 83-90. [CrossRef]

57. Kim, M.J.; Jun, H.Y.; Kim, J.H. Antiadipigenic effect of korean glasswort (Salicomia herbacea L.) water extract on 3T3-L1 adipocytes. J. Korean Soc. Food Sci. Nutr. 2014, 43, 814-821. [CrossRef] 
58. Kim, M.J.; Jun, H.Y.; Kim, J.H. Anti-obesity effect of korean hamcho (Salicomia herbacea L.) powder on high-fat diet-induced obese rats. J. Nutr. Health. 2015, 48, 123-132. [CrossRef]

59. Seo, H.B.; Kwak, Y.Y.; Nam, J.O.; Son, Y.J.; Kim, B.O.; Ryu, S.P. Glasswort powder diet activates lipid metabolism in rat. J. Life Sci. 2012, 22, 478-485. [CrossRef]

60. Lee, H.S.; Choi, J.H.; Kim, Y.E.; Lee, C.H. Effect of dietary intake of Salicornia herbacea L. hot water extract on anti-obesity in diet-induced obese rats. J. Korean Soc. Food Sci. Nutr. 2012, 41, 950-956. [CrossRef]

61. Kim, N.H.; Heo, J.D.; Rho, J.R.; Yang, M.H.; Jeong, E.J. Anti-obesity Effect of Halophyte Crop, Limonium tetragonum in High-Fat Diet-Induced Obese Mice and 3T3-L1 Adipocytes. Biol. Pharm. Bull. 2017, 40, 1856-1865. [CrossRef] [PubMed]

62. Jung, Y.Y. Effect of Oenanthe javanica extracts on fat accumulation of the liver in rats. Master's Thesis, Yeungnam University, Gyeongsan City, Korea.

63. Zar Kalai, F.; Han, J.; Ksouri, R.; Abdelly, C.; Isoda, H. Oral administration of Nitraria retusa ethanolic extract enhances hepatic lipid metabolism in db/db mice model 'BKS.Cg-Dock7(m)+/+ Lepr(db/) J' through the modulation of lipogenesis-lipolysis balance. Food Chem. Toxicol. 2014, 72, 247-256. [CrossRef] [PubMed]

64. Kim, K.R.; Choi, J.H.; Lee, S.K.; Woo, M.H.; Choi, S.W. Effect of enzymatic hydrolysate of Hamcho (Salicornia herbacea) on antioxidative defense system in rats fed high cholesterol diet. J. Korean Soc. Food Sci. Nutr. 2006, 35, 1356-1362. [CrossRef]

65. Kang, K.J.; Lim, S.J.; Jeong, J.G.; Han, H.K.; Choi, S.S.; Kim, M.H.; Kwon, S.Y. Effects of wax guard on weight, triglyceride, leptin and fat cell size in rats fed on a high fat diet. J. Nutr. Health. 2003, 36, 446-451.

66. Oka, S.; Alcendor, R.; Zhai, P.; Park, J.Y.; Shao, D.; Cho, J.; Yamamoto, T.; Tian, B.; Sadoshima, J. PPARalpha-Sirt1 complex mediates cardiac hypertrophy and failure through suppression of the ERR transcriptional pathway. Cell Metab. 2011, 14, 598-611. [CrossRef]

67. Karadeniz, F.; Kim, J.A.; Ahn, B.N.; Kim, M.; Kong, C.S. Anti-adipogenic and pro-osteoblastogenic activities of Spergularia marina Griseb. Prev. Nutr. Food Sci. 2014, 19, 187-193. [CrossRef]

(C) 2020 by the authors. Licensee MDPI, Basel, Switzerland. This article is an open access article distributed under the terms and conditions of the Creative Commons Attribution (CC BY) license (http://creativecommons.org/licenses/by/4.0/). 